Review Article

\title{
Local Drug Delivery in periodontal diseases. ......A Review
}

\section{Amitha Ramesh ${ }^{1}$, Agumbe Priyanka Prakash ${ }^{2} \&$ Biju Thomas $^{3}$}

${ }^{1}$ Professor, ${ }^{2}$ Post Graduate, ${ }^{3} \mathrm{HOD}$, Department of Periodontics,

A.B. Shetty M emorial Institute of Dental Sciences, Nitte University, Mangalore.

\author{
Correspondence \\ Agumbe Priyanka Prakash \\ Post Graduate, Department of Periodontics. \\ A.B. Shetty M emorial Institute of Dental Sciences, Nitte University, M angalore - 575 018, Karnataka, India. \\ Mobile : +919449752055 E-mail : agumbe.priyanka@yahoo.co.in
}

\begin{abstract}
Periodontitis is an immuno-inflammatory disease of the tissues surrounding the teeth. Various treatment modalities like mechanical debridement and use of antimicrobials have been followed in the treatment of such conditions. Introduction of local drug delivery system in the periodontal pocket is a promising therapeutic modality for achieving better clinical outcomes when used as an adjunct to conventional non surgical periodontal therapy. Intensive research efforts are now focussed on the development of new strategies for more effective treatment.
\end{abstract}

Keywords: Periodontitis, local drug delivery, scalingand root planning, antimicrobial agent.

\section{Introduction}

The inflammation in the periodontal tissue is initiated by microbial plaque and bacterial infection. In the periodontal pocket the bacteria form a highly structured and complex biofilm. As this continues, the biofilm reach far subgingivally and it becomes difficult for the patient to reach it during oral hygiene practices. ${ }^{1}$ Traditional treatment options for such conditions includes mechanical debridement aimed at removing the subgingival flora and providing a clean, smooth and compatible root surfaces. But, in several instances, the complex anatomy of the root and the location of the lesion may hamper the treatment and prevent sufficient reduction of the bacterial load. ${ }^{2}$

Antibacterial agents have been used along with mechanical debridement in the management of periodontal infection. The effectiveness of all the methods are limited due to the lack of accessibility in the Access this article online Quick Response Code

四得国
periodontal pocket. ${ }^{3}$ Periodontal pocket provides an ideal environment for the growth of anaerobic pathogenic bacteria such as Actinobacillus actinomycetem comitans, Porphyromonas gingivalis and Provetella intermedia. For the effective treatment, the antibiotic must reach the depth of the pocket and produce gingival fluid concentrations higher than the minimum inhibitory concentrations (MIC) of the suspected pathogens. ${ }^{4}$ Recent advance in science and technology has revolutionized the basic outlook and approach to the problems of periodontal disease. Earlier it was assumed that periodontal problems were invariably progressive and the morbid effects increase with passage of time. A thorough understanding of the etiopathogenesis of periodontal disease has provided the clinicians and researchers with a number of diagnostic tools and technique that has widened the treatment options. ${ }^{5}$

\section{History}

Ever since the introduction of systemic antibiotics, various drugs have been used in the treatment of periodontitis. The disadvantages of systemic antibiotics like bacterial resistance, superimposed infections, uncertain patient compliance, nausea, vomiting and gastrointestinal disturbances ${ }^{6}$ led to the introduction of local drug delivery as the treatment option. It was in the year 1979, Dr. Max Goodson et al first proposed the concept of controlled delivery in the treatment of periodontitis. ${ }^{7}$ Since then, a number of studies have been carried out over the years 
with different antimicrobial agents and in different clinical situations.

\section{Classification}

Various classification systems were evolved.

\section{Based on the application [Rams and Slots] 1996}

1. Personally applied (in patient home self-care)

A. Nonsustained subgingival drug delivery Home oral irrigation Home oral irrigation jet tips

Traditional jet tips

Oral irrigation (water pick)

Soft cone rubber tips (pick pocket)

B. Sustained subgingival drug delivery

2. Professionally applied (in dental office)

A. Nonsustained subgingival drug delivery

Professional pocket irrigation

B. Sustained subgingival drug delivery

Controlled release devices

Hollow fibres

Dialysistubing

Strips

Films ${ }^{8}$

\section{Based on the duration of medicament release}

(Greenstein and Tonetti 2000) $^{9}$

A. Sustained release devices - Designed to provide drug delivery for less than 24 hours

B. Controlled release devices - Designed to provide drug release that at least exceeds 1 day or for at least 3 days following application (Kornman1993)

\section{Dependingon degradability.}

1. Nondegradable devices (first generation)

2. Degradable devices (second generation) ${ }^{5}$

Various drug delivery systems for treating periodontitis are fibres, films, injectable systems, gels, strips, compacts, vesicular system, microparticles and nanoparticles. ${ }^{3}$

Currently available locally delivered antimicrobials in periodontal therapy,
Tetracycline: containing fibers are the first available local drug. It had ethylene/vinyl acetate copolymer fiber with diameter of $0.5 \mathrm{~mm}$, containing tetracycline $12.7 \mathrm{mg}$ per 9 inches. ${ }^{1}$ The Actisite tetracycline fibres have been approved both by the United States Food and DrugAdministration (FDA) and by the European Union's regulatory agencies. These are non-resorbable, safe, inert copolymer loaded with $25 \% \mathrm{w} / \mathrm{w}$ tetracycline $\mathrm{HCl}$.It maintains constant concentrations more than $1000 \mu \mathrm{g} / \mathrm{mL}$ for a period of 10 days. Follow up showed reduction in the subgingival microbiota. ${ }^{2}$ Bioresorbable tetracycline fibre has been developed with base of collagen film, which is commercially available as Periodontal Plus AB. It offers the advantage of no second appointment for removal as it degrades within 7 days. ${ }^{10}$ Tetracycline seratiopeptidase containing gels were evaluated in a study by $M$ aheshwari et al 2005. This combination containing thermoreversible gel was clinically effective along with scaling and root planing. ${ }^{11}$ Various studies were conducted with tetracycline as monotherapy and also as an adjunctive to scaling and rootplaning. In a 6-month multi-center evaluation of adjunctive tetracycline fiber therapy by Newman et al 1994, showed that fiber therapy significantly enhanced the effectiveness of scaling and root planing in the management of localised recurrent periodontitis sites, in patients receiving regular supportive periodontal therapy.

Doxycycline : Atridox is a FDA approved $10 \%$ doxycycline in a gel system using a syringe. ${ }^{1}$ GCF levels reached its peak to 1,500-2,000 in 2 hours following treatment with Atridox. These levels remained above $1000 \mu \mathrm{g} / \mathrm{mL}$ through 18 hours, and then levels gradually declined. ${ }^{2}$ Walker et al 2000 in an attempt to determine the effectiveness of sustained-release, biodegradable gel containing 8.5\% doxycycline on the anaerobic flora and on antibiotic susceptibility patterns associated with subgingival plaque and saliva reported that the treatment significantly reduced the anaerobic population in plaque but did not result in change in either number of resistant bacteria or the acquisition of antibiotic resistance. ${ }^{13}$ 
M inocycline - Arestin is a FDA approved locally delivered, sustained release form of minocycline microspheres for subgingival placement. The $2 \%$ minocycline is encapsulated into bioresorbable microspheres in gel carrier. ${ }^{1}$

Stefan Renvert et al 2008, conducted a study to compare

Various agents available in market ${ }^{2,25}$ :

\begin{tabular}{|c|c|c|}
\hline \multirow{2}{*}{$\begin{array}{l}\text { Agent } \\
\text { Tetracycline }\end{array}$} & Product available & Dosage form \\
\hline & $\begin{array}{l}\text { Actisite ( } 25 \% \text { w/v tetracycline } \mathrm{Hcl}) \\
\text { Periodontal plus } \mathrm{AB} \text { ( } 2 \mathrm{mg} \text { of } \\
\text { Tetracycline in } 25 \mathrm{mg} \text { of collagen) }\end{array}$ & $\begin{array}{l}\text { Non resorbable fiber } \\
\text { Resorbable fiber }\end{array}$ \\
\hline Doxycycline & Atridox (10\% Doxycycline) & Bio degradable mix in syringe. \\
\hline M inocycline & $\begin{array}{l}\text { Dentomycin gel ( } 2 \% \text { M inocycline) } \\
\text { Arestin ( } 2 \% \text { M inocycline) } \\
\text { Periocline (2.1\%w/v M inocycline) }\end{array}$ & $\begin{array}{l}\text { Biodegradable gel } \\
\text { Biodegradable mix in syringe } \\
\text { Ointment }\end{array}$ \\
\hline Metronidazole & Elyzol (25\% M etronidazole) & biodegradable gel \\
\hline Chlorhexidine & $\begin{array}{l}\text { Periochip ( } 2.5 \mathrm{mg} \text { Chlorhexidine) } \\
\text { Periocol CG ( } 2.5 \mathrm{mg} \text { Chlorhexidine) } \\
\text { Chlosite ( } 1.5 \% \text { Chlorhexidine) }\end{array}$ & $\begin{array}{l}\text { Biodegradable chip } \\
\text { Biodegradable chip }\end{array}$ \\
\hline
\end{tabular}

Recently various newer drugs have been tried to determine their efficacy.

\begin{tabular}{|c|c|c|}
\hline Authers & Aim of the study & Major outcome \\
\hline $\begin{array}{l}\text { Vijay Kumar Chava } \\
\text { et } \mathrm{al}^{17}\end{array}$ & $\begin{array}{l}\text { develop a thermo-reversible sustained-release } \\
\text { green tea gel and effects on patients } \\
\text { with chronic periodontitis. }\end{array}$ & $\begin{array}{l}\text { use of local application of green tea gel along with } \\
\text { conventional therapy showed greater reduction of } \\
\text { pocket and inflammation. }\end{array}$ \\
\hline A R Pradeep et al ${ }^{18}$ & $\begin{array}{l}\text { the efficacy of varying concentrations of } \\
\text { subgingivally delivered } 0.5 \%, 1 \% \text {,metformin in } \\
\text { the treatment of chronic periodontitis }\end{array}$ & $\begin{array}{l}\text { mean reduction of pocket depth and mean clinical } \\
\text { attachment level was greater in metformin group } \\
\text { than the placebo group. The greatest reduction } \\
\text { was found in } 1 \% \text { metformin group. }\end{array}$ \\
\hline A R Pradeep et al ${ }^{19}$ & $\begin{array}{l}\text { to evaluate the efficacy of subgingivally } \\
\text { delivered } 1.2 \% \text { Atorvastatin in patients with } \\
\text { chronic periodontitis }\end{array}$ & $\begin{array}{l}\text { mean pocket depth, clinical attachment level gain } \\
\text { was greater in patients with Atorvastatin than the } \\
\text { placebo. }\end{array}$ \\
\hline Ray C Williams et al $^{20}$ & M inocycline spheres in chronic periodontitis & $\begin{array}{l}\text { mean reduction of probing depth was improved in } \\
\text { group receiving minocycline spheres along with } \\
\text { scaling root planing when compared to group with } \\
\text { Scaling and root planing alone. }\end{array}$ \\
\hline Amitha Ramesh et $\mathrm{al}^{21}$ & $\begin{array}{l}\text { evaluation of subgingival application of } \\
\text { chlorhexidine varnish and chlorhexidine gel } \\
\text { as an adjunct to full mouth scaling and root } \\
\text { planing in case of moderate to deep } \\
\text { periodontal pocket subjects. }\end{array}$ & $\begin{array}{l}\text { combination of varnish and gel with scaling and } \\
\text { root planing had better clinical outcome. }\end{array}$ \\
\hline Esha Agarwal et al ${ }^{22}$ & $\begin{array}{l}\text { Efficacy of } 0.5 \% \text { Clarithromycin gel with and } \\
\text { without scaling root planing }\end{array}$ & $\begin{array}{l}\text { improved clinical outcomes in Clarythromycin gel } \\
\text { and scaling and root planing when compared to } \\
\text { group that received scaling and root planing alone }\end{array}$ \\
\hline A R Pradeep et al $^{23}$ & $\begin{array}{l}\text { Efficacy of1 \% Alendronate } \\
\text { gel in intrabony defects. }\end{array}$ & $\begin{array}{l}\text { greater mean percentage of bone fill, probing } \\
\text { depth reduction and clinical attachment gain was } \\
\text { seen in the group receiving alendronate gel than } \\
\text { placebo. }\end{array}$ \\
\hline A R Pradeep et $\mathrm{al}^{24}$ & $\begin{array}{l}\text { Efficacy of } 1 \% \text { Alendronate gel in class II } \\
\text { Furcation defects }\end{array}$ & $\begin{array}{l}\text { mean probing depth reduction, mean relative } \\
\text { vertical and horizontal clinical attachment level in } \\
\text { group that received gel in class II furcation defects } \\
\text { compared to placebo. }\end{array}$ \\
\hline Renvert et al ${ }^{15}$ & $\begin{array}{l}\text { local minocycline microspheres or } \\
\text { chlorhexidine gel following debridement in } \\
\text { periimplantitis cases. }\end{array}$ & $\begin{array}{l}\text { use of minocycline resulted in Significant } \\
\text { reduction in mean probing pocket depths. }\end{array}$ \\
\hline
\end{tabular}



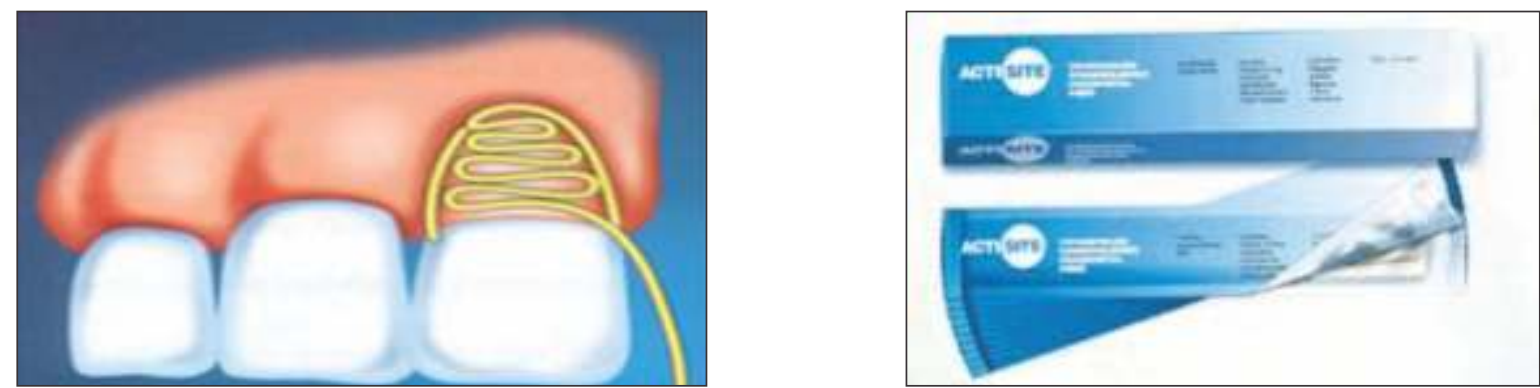

$25 \% \mathrm{w} / \mathrm{v}$ tetracycline $\mathrm{HCl}$
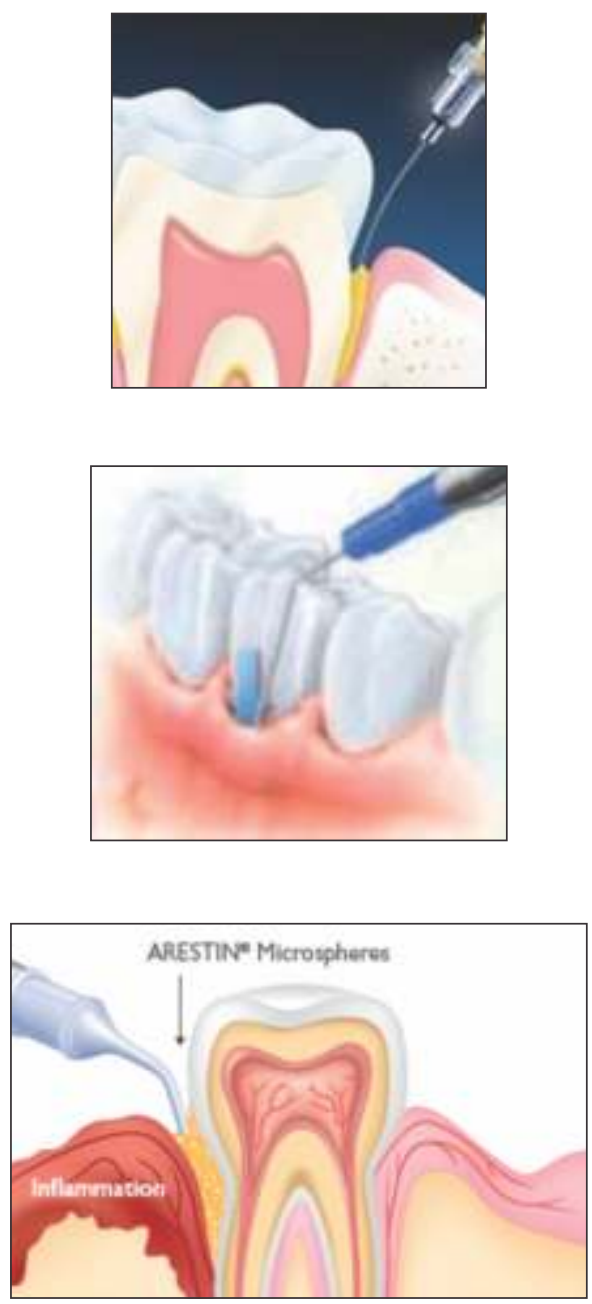

2\% M inocycline

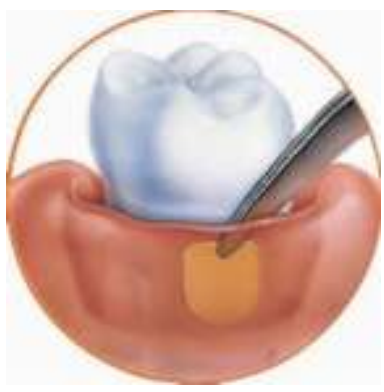

10\% Doxycycline
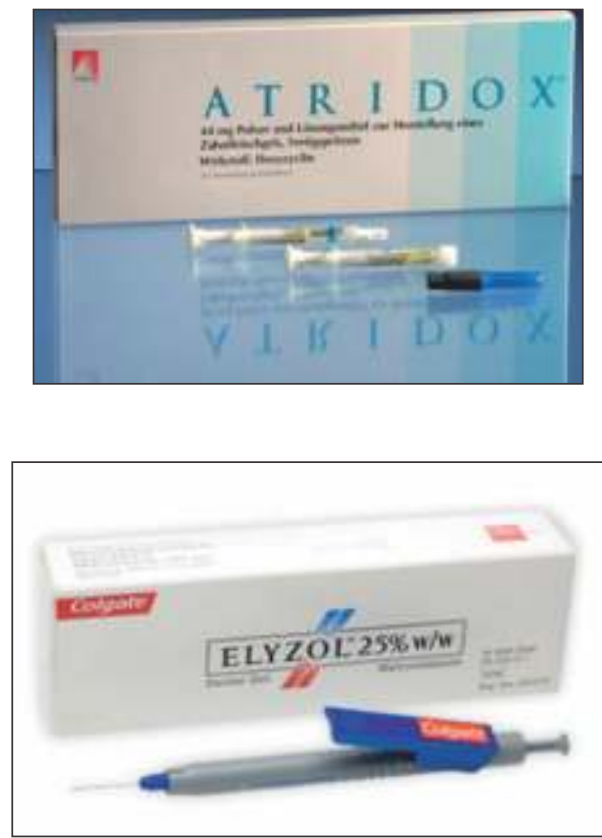

$25 \%$ Metronidazole
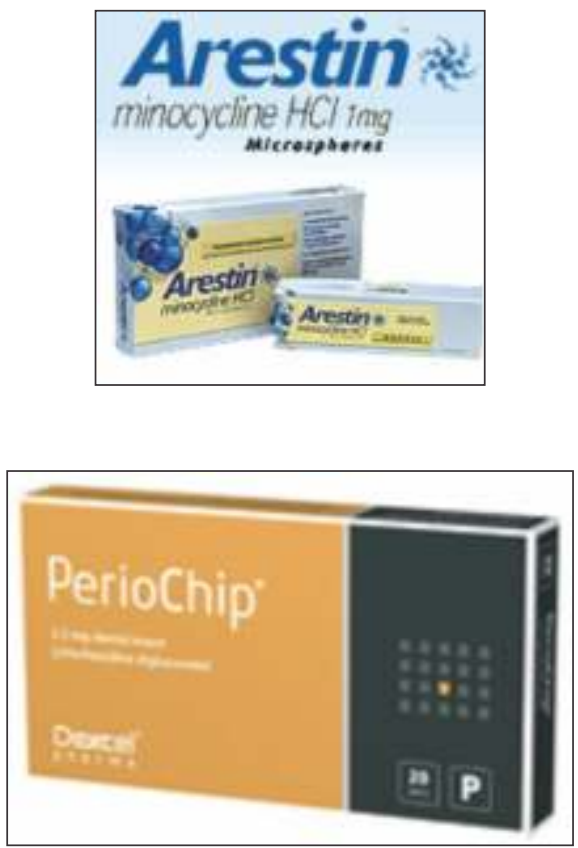

2.5mg Chlorhexidine 
minocycline on probing depths with chlorhexidine at days 30,90 , and 180 ( $P=0.5, P=0.01$, and $P=0.04$, respectively). The use of repeated local antibiotic as an adjunct to the mechanical treatment of peri-implantitis lesions demonstrated improvements in probing depths that were significantly different from controls and were sustained for 6 months. It was concluded that for greater benefit the treatment may have to be repeated. ${ }^{14}$

Metronidazole : Elyzol is a topical medication containing an oil-based metronidazole $25 \%$ dental gel , applied in viscous consistency to the pocket. ${ }^{1}$ YealShifrovitch et al 2009 in a study enabled the understanding of metronidazolerelease kinetics from bioabsorbable polymeric films and demonstrated good biocompatibility and the ability to inhibit Bacteroides fragilis growth; therefore, they may be useful in the treatment of periodontal diseases. ${ }^{15}$

Chlorhexidine : Periochip is a small chip composed of biodegradable hydrolysed gelatin matrix, cross-linked with glutaraldehyde and also containing glycerine and water, into which $2.5 \mathrm{mg}$ of chlorhexidine gluconate has been incorporated per chip. It is a FDA approved small, orange brown, chip measuring $4.0 \times 0.5 \times 0.35 \mathrm{~mm}$ in a biodegradable matrix of hydrolysed gelatin.

Studies showed reduction in the numbers of the putative periodontopathic organisms Porphyromonas gingivalis,

\section{References}

1. Newman, Takei, Klokkevold, Carranza. Carranza's clinical periodontology 2010;pp 798-803, Chemotherapeutic agents, $10^{\text {th }}$ edition.2010; Elsevier, Reed Elsevier India Private Limited.

2. Dodwad V, Vaish S, Mahajan A, Chhokra M. Local drug delivery in periodontics: a strategic intervention. International Journal of Pharmacy and Pharmaceutical Sciences.2004;4(4):30-4.

3. Pragati $\mathrm{S}$, Ashok S., KuldeepS. Recent advances in periodontal drug delivery systems. International Journal of Drug Delivery Jan 2009;1 : 19.

4. Gordon JM, Walker CB.Current status of systemicantibiotic usage in destructive periodontal disease.J Periodontol 1993; 64: 760-771.

5. Divya P.V, K. Nandakumar: "Local Drug Delivery---Periocol" In Periodontics;trendsbiometer. Artif.Organs.2010; 19(2): 74-80.

6. Chadha VS, Arora K, M anjunath B C, SarikaKalra: local drug delivery in periodontics: current concepts and trends; International Journal of Advanced Research On Oral Sciences 2012; 1(1): 1-9.

7. Goodson JM, Hafajee A, Socransky SS. Periodontal therapy by local delivery of tetracycline.J Clinical Periodontol 1979; 6: 83-92.

8. Rams TE, Slots J. Local delivery of antimicrobial agents in the periodontal pocket. Periodontology 2000. 1996 Feb ; 10: 139-159.

9. Greenstein G, Tonetti M. The role of controlled drug delivery for periodontitis. The Research, Science and Therapy Committee of the
Prevotella intermedia, Bacteroides forsythus, and Campylobacter rectus after placement of the chip. ${ }^{2}$ Study by Soskolne W.A in 1999 showed that there was an initial peak concentration of chlorhexidine in gingival crevicular fluid at 2 hour after the chip was introduced. Slightly lower concentrations being maintained over next $96 \mathrm{hrs}$. Total degradation occurred between 7-10 days after insertion. ${ }^{16}$

\section{Conclusion}

Based on the available evidence, the local drug delivery into the periodontal pocket can improve the periodontal health. However these drugs fail to completely replace the conventional scaling and root planning. Thus the benefit of these drugs as a mono therapy is questionable. When compared to systemic antimicrobials, the local drug delivery will reduce the developing drug resistant bacterial strain which is of current worldwide concern. Also, the controlled release properties can be applied as a therapeutic component in the effective management of localised persisting lesions. Local drug administration should be based on patient clinical findings, scientific evidence and proper diagnosis.

Thus, it can be concluded that local drug delivery though not a substitute for the conventional therapy, can be of added benefit if used as an adjunct with the conventional scaling and root planning.

American Academy of Periodontology. J Periodontl 2000 Jan; 71(1):125-140.

10. Ashtaputre V,Limaye M . Local drug delivery in periodontics:A tactical entreaty. Journal of Research in Pharmaceutical Science2014; 2 (1): 06-11.

11. Maheshwari M , M iglani G, M ali A, Paradkar A, Yamamura S, Kadam S. Development of Tetracycline-Serratiopeptidase- Containing Periodontal Gel: Formulation and Preliminary Clinical Study; AAPS Pharm Sci Tech 2006; 7 (3):162-171.

12. Newman MG, Kornman KS, Doherty FM. A 6-month multi-center evaluation of adjunctive tetracycline fiber therapy used in conjunction with scaling androot planing in maintenance patients:clinical results. J PeriodontolJuly 1994; 65: 685-691.

13. Walker C, Godowski K, Borden L, Lennon J, Nango S, Stone C, \& Garrett S.The effects of sustained release doxycycline on the anaerobic flora and antibiotic -resistant patterns in subgingival plaque and saliva. JPeriodontol 2000;71:768-774.

14. Renvert S, Lessem J, Dahlen G, Renvert H,Lindahl C. Mechanical and Repeated AntimicrobialTherapy Using a Local Drug DeliverySystemin theTreatment of Peri-Implantitis:A Randomized Clinical Trial. J Periodontol 2008; 79: 836-844.

15. Shifrovitch Y, Binderman I, Bahar H, Berdicevsky I, Zilberman M 
Metronidazole-Loaded Bioabsorbable Films as Local Antibacteria Treatmentof Infected Periodontal Pockets. J Periodontol 2009;80:330-

16. Varma A, Sanghi S, Grover D, Aggarwal S, Gupta R, Pandit N. Effect of insertion of xanthan-based chlorhexidine gel in the maintenance phase following the treatment of chronic periodontitis. J Indian Soc Periodontol. 2012 Jul-Sep; 16(3): 381-5.

17. Chava VK, Vedula BD. Thermo-reversible green tea catechin gel for local application in chronic periodontitis: a 4-week clinical trial. J Periodontol 2013;84:1290-6.

18. Pradeep AR, Rao NS, Naik SB, Kumari M. Efficacy of varying concentrations of subgingivally delivered metformin in the treatment of chronic periodontitis: a randomized controlled clinical trials. J of Periodontal. Feb 2013;84:133-135.

19. Pradeep AR, Kumari M, Rao NS, M artande SS, Naik SB. Clinical Efficacy of subgingivallydelivered $1.2 \%$ Atorvastatin in chronicperiodontitis: A Randomized Controlled Clinical Trial. Journal of Periodontology. July 2013; 84(7): 871-9

20. Williams RC, Paquette DW, Offenbacher S. Treatment of periodontitis by local administration of minocycline microspheres: a controlled trial. Journal of Periodontology. November 2001;72(1):11-4
21. Ramesh A, Thomas B, Sathish M. Comparative evaluation of subgingival application of chlorhexidine varnish and chlorhexidine gel as an adjunct to full mouth scaling and root planing in the treatment of moderate to deep periodontal pockets -Aclinical study.JIDA2010;8 3):35-40.

22. Agarwal E, Pradeep AR, Bajaj P, Naik SB. Efficacy of local drug delivery of $0.5 \%$ Clarithromycin gel as an adjunct to non-surgical periodontal therapy in the treatment of current smokers with chronic periodontitis: A randomized controlled clinical trial. J.Periodontal September 2012;83:1155-1163.

23. Pradeep AR, Sharma A, Rao NS, Bajaj P, Naik SB, Kumari M . Local drug delivery of alendronate gel for the treatment of patients withchronic periodontitis with diabetes mellitus: a double-masked controlledclinicaltrial;j. Periodontal .oct 2012; 83(10):1322-8.

24. Pradeep AR, Kumari M, Rao NS, Naik SB .1\% Alendronate gel as local drugdelivery in the treatment of class iifurcation defects: a randomizedcontrolled clinical trial.j.periodontal march 2012; vol 84( 3):307-315

25. Baiju CS, Manchanda $S$.Chair side therapeutic aids in periodontics Heal talk. Nov-Dec 2010;3(2):41-2. 